\title{
Toxoplasma gondii in goats from Curitiba, Paraná, Brazil: risks factors and epidemiology
}

\author{
Toxoplasma gondii em caprinos de Curitiba, Paraná, Brasil: fatores de risco e epidemiologia \\ Guilherme Garcia' ${ }^{1}$ Cristina Sotomaior ${ }^{2}$; Aguinaldo José do Nascimento ${ }^{3}$; \\ Italmar Teodorico Navarro ${ }^{4}$; Vanete Thomaz Soccol ${ }^{5,6 *}$
}

\begin{abstract}
${ }^{1}$ Programa de Pós-graduação em Microbiologia, Parasitologia e Patologia, Laboratório de Parasitologia Molecular, Departamento de Patologia Básica, Universidade Federal do Paraná - UFPR

${ }^{2}$ Departamento de Medicina Veterinária, Pontifícia Universidade Católica do Paraná - PUCPR

${ }^{3}$ Departamento de Farmácia, Universidade Federal do Paraná - UFPR

${ }^{4}$ Departamento de Medicina Veterinária Preventiva, Universidade Estadual de Londrina - UEL

${ }^{5}$ Laboratório de Parasitologia Molecular, Universidade Federal do Paraná - UFPR

${ }^{6}$ Divisão de Biotecnologia, Universidade Positivo
\end{abstract}

Received April 26, 2011

Accepted July 272011

\begin{abstract}
Toxoplasmosis is a zoonosis caused by Toxoplasma gondii, a protozoan with wide geographical distribution and minimal parasitic specificity that affects many species of wild and domestic animals. In livestock, especially in small ruminants like goats, toxoplasmosis can cause abortion and the birth of weak animals, leading to economic losses to farmers, and is a major source of human infection. This is a seroepidemiological study of toxoplasmosis in goats in the state of Paraná, Brazil. Sera from 405 goats from the metropolitan mesoregion of Curitiba, eastern state, were tested by the enzyme-linked immunosorbent assay (ELISA) and indirect immunofluorescence antibody test (IFAT). Information on properties and goat characteristics was also collected using questionnaires. The prevalence of toxoplasmosis was 39.41 and $35.96 \%$ by ELISA and IFAT, respectively. T. gondii antibody prevalence increased with age. The risk factors for T. gondii infection in goats were: age over one year; exposure to cats, type of management and purpose of breeding. Other epidemiological factors and relevant control measures are discussed in the current study.
\end{abstract}

Keywords: Toxoplasma gondii, seroepidemiology, risk factors.

\section{Resumo}

A toxoplasmose é uma zoonose causada pelo Toxoplasma gondii, um protozoário com vasta distribuição geográfica e pouca especificidade parasitária, que pode afetar muitas espécies de animais selvagens e domésticos. Em animais de produção, especialmente pequenos ruminantes, como caprinos, pode provocar abortos e nascimento de crias fracas, causando perdas econômicas para os criadores, além de ser uma importante fonte de infecção humana. Este é um estudo soroepidemiológico para toxoplasmose caprina no Estado do Paraná. Soros de 405 caprinos da mesorregiáo metropolitana de Curitiba, no leste paranaense foram avaliados pelas técnicas de imunoensaio enzimático (ELISA) e reação de imunofluorescência indireta (RIFI), além da avaliação de questionários com dados das propriedades e animais estudados. A prevalência encontrada foi de 39,41 e 35,96\% para as técnicas ELISA e RIFI, respectivamente. A prevalência de anticorpos anti-T. gondii aumenta com a idade dos animais. Os fatores de risco para infecção por T. gondii em caprinos encontrados neste estudo são: idade acima de um ano, presença de gatos, tipo de manejo e propósito da criação. Outros fatores epidemiológicos e medidas de controle são discutidos no presente trabalho.

Palavras chave: Toxoplasma gondii, soroepidemiologia, fatores de risco.

\footnotetext{
*Corresponding author: Vanete Thomaz Soccol

Universidade Positivo, Rua Pedro Viriato Parigot de Souza, 5300,

Campo Comprido, CEP 81280-330, Curitiba, PR, Brasil

e-mail: vsoccol@up.edu.br
} 


\section{Introduction}

Toxoplasma gondii is a coccid parasite for which cats are the definitive host and warm blood animals act as intermediate hosts (FRENKEL et al., 1970). It is present almost worldwide and is of medical and veterinary importance because it can cause miscarriages and birth defects in intermediate hosts (TENTER et al., 2000).

Feldman and Miller (1956) were the first to report toxoplasmosis in goats, examining livestock in New York State. From then on, the disease has been identified as a major cause of reproductive problems in sheep and goats in many countries (SKJERVE et al., 1998; BORDE et al., 2006). T. gondii infection can cause neonatal mortality and abortion at different gestational ages, fetal mummification, stillbirth or perinatal mortality (BLEWETT, 1983).

Studies conducted in Uruguay showed that toxoplasmosis is an important problem in sheep, causing annual losses of US\$1.4 to 4.7 million (FREYRE et al., 1999). Munday and Mason (1979) were the first to describe toxoplasmosis as an important cause of reproductive losses in goats. Despite less documented in goats, it seems to cause much more damage in these animals and adult goats are also clinically affected (DUBEY, 1987).

Several epidemiological studies have been performed in Brazil where toxoplasmosis prevalence varies from 10 to $92.4 \%$, according to geographical region and diagnostic technique used (Table 1).

There is concern about the transmission of $T$. gondii through in natura goat milk and its products as well as goat meat and byproducts when these are consumed by humans. The consumption of poorly pasteurized goat milk is a great public health concern. Toxoplasmosis has become one of the most widespread zoonoses as goats with acute infection can eliminate tachyzoites through their milk (SKINNER et al., 1990; VITOR et al., 1991).

Silva Filho et al. (2008), in the municipality of Guarapuava, southern state of Paraná, described an outbreak of abortion in a goat herd occurred between June and July 2005, there were in the property 304 goats and $89.1 \%$ of them showed anti- T. gondii antibodies by IFAT. From 136 pregnant 61 miscarried, and of these, 59 had titers positive for $T$. gondii. The epidemic outbreak in this property was an atypical event. However, little data is available on the importance of this animal species for the maintenance of T. gondii life cycle in the state of Paraná where goat meat and milk production is a major industry. There is a lack of data on the current prevalence of anti- $T$. gondii antibodies in goats and whether the rate of anti- $T$. gondii antibodies is similar in all herds. ELISA and IFAT techniques were used in this serological study and the main risk factors for goat toxoplasmosis were assessed.

\section{Materials and Methods}

Sera from 405 goats of 12 livestock in the metropolitan mesoregion of Curitiba, state of Paraná, southern Brazil (252 $25^{\prime} 40^{\prime \prime} \mathrm{S}$ and $\left.49^{\circ} 16^{\prime} 00^{\prime \prime} \mathrm{W}\right)$, were analyzed. The minimum number of sera to be tested was calculated assuming a 50\% prevalence, $95 \%$ confidence interval and 5\% precision (THRUSFIELD, 2004). Blood samples were collected by jugular venipuncture and sera were separated,

Table 1. Prevalence of toxoplasmosis in goats in Brazil according to state and year.

\begin{tabular}{|c|c|c|c|c|}
\hline Author (year) & Region/State & No of animals & T. gondii (\%) & Technique (cut-off) \\
\hline Araújo Neto et al. (2008) & $\mathrm{RN}$ & 366 & 30.6 & IFAT (64) \\
\hline Silva et al. (2003) & $\mathrm{PE}$ & 213 & 40.4 & IFAT (16) \\
\hline Alves et al. (1997) & $\mathrm{PB}$ & 631 & 0 to 26.8 & IFAT \\
\hline Faria et al. (2007) & $\mathrm{PB}$ & 306 & 24.5 & IFAT (64) \\
\hline Cavalcante et al. (2008) & $\mathrm{CE}$ & 2362 & 25.1 & ELISA \\
\hline Pita-Gondin et al. (1999) & BA & 439 & 28.93 & Latex agglutination (64) \\
\hline Uzêda et al. (2004) & BA & 373 & 16.35 & IFAT (16) \\
\hline Chiari et al. (1987) & MG & 343 & 68.0 & IFAT \\
\hline Chiari et al. (1987) & MG/BH & & 92.4 & IFAT \\
\hline Figueiredo et al. (2001) & MG & 174 & 19.0 & HAI \\
\hline Figueiredo et al. (2001) & MG & 174 & 19.5 & IFAT (64) \\
\hline Figueiredo et al. (2001) & MG & 174 & 19.5 & ELISA \\
\hline Carneiro et al. (2009) & MG & 767 & 43.0 & ELISA \\
\hline Carneiro et al. (2009) & MG & 767 & 46.0 & IFAT (64) \\
\hline Mainardi et al. (2000) & SP & 442 & 14.47 & IFAT (16) \\
\hline Silva et al. (2002) & SP & 100 & 8.0 & IFAT \\
\hline Silva et al. (2002) & SP & 100 & 11.0 & MAD \\
\hline Meireles et al. (2003) & SP & 200 & 17.0 & ELISA \\
\hline Figliuolo et al. (2004) & SP & 394 & 28.68 & IFAT (64) \\
\hline Modolo et al. (2008) & SP & 923 & 23.4 & IFAT (16) \\
\hline Sella et al. (1994) & PR & 153 & 30.71 & IFAT (64) \\
\hline Maciel and Araújo (2004) & RS & 360 & 19.4 & HAI \\
\hline Maciel and Araújo (2004) & RS & 360 & 30.0 & IFAT \\
\hline
\end{tabular}

SP: São Paulo; RN: Rio Grande do Norte; RS: Rio Grande do Sul; Sul; PR: Paraná; PE: Pernambuco; MG: Minas Gerais; BH: Belo Horizonte; CE: Ceará; PB: Paraíba. 
identified and stored at $-20{ }^{\circ} \mathrm{C}$ until their use. Information on the epidemiology of toxoplasmosis including property location, facilities, presence of other animals, sanitary conditions, type of handling and livestock exploration and sex and age of goats were collected. Two techniques were used to detect anti- $T$. gondii IgG antibodies in the sera, indirect immunofluorescence antibody test (IFAT) and immunoenzymatic assay (ELISA).

For both techniques, antigens were from tachyzoites obtained by in vitro culture. The standard RH strain was grown in Vero cell and RPMI Medium $1640\left(\mathrm{GIBCO}^{\mathrm{TM}}\right)$ was the culture medium containing $2 \%$ sodium bicarbonate with $10 \%$ fetal calf serum. Culture bottles were then left in a carbon dioxide heater at $37^{\circ} \mathrm{C}$ and $5 \% \mathrm{CO}_{2}$ until cell growth was visible and the monolayer had been established. Next, cells were infected with tachyzoites and growth or contamination of culture bottles was examined under an inverted microscope at 250 and $400 \times$ magnification. After more than $75 \%$ of the monolayer had been destroyed, the medium was removed to a $50 \mathrm{~mL}$ Falcon tube, the bottle was scraped with a rubber rod and washed with sterile PBS, $\mathrm{pH} 7.2$, and this PBS was placed in the same Falcon tube. The contents were passed through a $15 \times 6$ needle to rupture the Vero cells. Fragments were placed between a slide and cover slip and examined under a light microscope to check for cell rupture and tachyzoite release. The Falcon tube containing the liquid fraction of the bottle was centrifuged at $2500 \mathrm{x} \mathrm{g}$ for 10 minutes. The supernatant was discarded and the pellet was diluted in PBS, pH 7.2, and used for the production of intact (IFAT) or soluble antigen (ELISA).

IFAT was performed according to Camargo (1964). Fixed slides with standard amounts of antigen were used. The parasites were counted in a Thoma chamber, several concentrations of tachyzoites per $\mu \mathrm{L}(1600,800,400,200,100,50,25)$ were tested, and $20 \mu \mathrm{L}$ of tachyzoite solution per spot were added. The best concentration was 200 tachyzoites per $\mu \mathrm{L}$ or 4000 parasites per spot, i.e., 100 to 150 parasites per field at $400 \mathrm{x}$ magnification, which allows reading and visualization of parasite outline fluorescence. Sera were initially diluted at $1: 16$ and 1:64. Sera that were reactive at 1:64 were also tested at dilutions of 1:256, 1:1024, 1:4096 and $1: 16384$. Following evaluation in triplicate of different conjugate dilutions against different serum dilutions, a dilution of 1:200 was selected as it allowed good differentiation between positive and negative sera. The conjugate used was anti-caprine IgG FITC (whole molecule, SIGMA). The reaction was considered positive when titers were equal to or greater than 1:64.

For ELISA antigens were obtained from tachyzoites disrupted by five cycles of freezing $\left(-196^{\circ} \mathrm{C}\right)$ and thawing $\left(+37^{\circ} \mathrm{C}\right)$ followed by ultrasound (for 1 minutes three times at $60 \mathrm{~Hz}$, Bandelin Sonoplus HD 2070), centrifuged (9000 x g 30 minutes) and filtered $(0,22 \mu \mathrm{M})$. The protein was dosed by Bradford method (BRADFORD, 1976). The soluble antigen obtained was diluted in sodium carbonate-bicarbonate buffer, $\mathrm{pH}$ 9.6, at concentrations of 250, 500, 1000 and $2000 \mathrm{ng} \cdot \mathrm{mL}^{-1}$, which were tested for standardization. To each plate wells (Nunclon, cat $n^{\circ}$ 167008) $100 \mu \mathrm{L}$ of the soluble antigen were added and incubated in a humidity chamber at $4{ }^{\circ} \mathrm{C}$ for 12 to 14 hours. The plate was washed three times with $0.01 \mathrm{M} \mathrm{PBS}, \mathrm{pH} 7.4$, containing $0.05 \%$ Tween 20 or 80 (PBST). Blockage of the wells was performed with $200 \mu \mathrm{L}$ of $0.05 \mathrm{M}$ sodium carbonate-bicarbonate buffer solution, $\mathrm{pH}$ 9.6, which was removed by three washes with PBST. First, two positive and two negative control sera were tested at different concentrations of the antigen protein (1000 and $2000 \mathrm{ng}$ per well) and different conjugate dilutions (1:5,000, 1:10,000, $1: 20,000$ and $1: 40,000)$ and sera $(1: 100,1: 200$ and 1:400). Standardization was achieved by assessing the best combination of serum dilution, conjugate dilution and antigen concentration with the least amount of expensive reagents (conjugate) or those difficult to obtain (antigen and serum).

The purpose of the test was considered to establish the cutoff for ELISA. A high sensitivity was chosen because the purpose was to assess the seroprevalence of anti-T. gondii antibodies in goats. Thus, the cutoff was calculated from the mean of eight negative control sera plus twice the standard deviation.

For statistical analysis, a database was created based on epidemiological data and serological results. Comparisons were made between positive and negative rates, and goat sex and age. Data were analyzed by z-test probabilities (mutually exclusive categories) and the chi-square test $\left(\chi^{2}\right)$, followed by z-test of standardized residuals (HABERMAN, 1973). The risk factors for goat toxoplasmosis were also defined according to ELISA, by calculating the relative risk for each factor (THRUSFIELD, 2004). The statistical significance was set at $\mathrm{p} \leq 0.05$.

This study was approved by the Animal Experimentation Ethics Committee of the Universidade Federal do Paraná Biological Sciences Department under protocol no 427.

\section{Results}

Seropositive goats were found in all herds. The prevalence rates varied among the farms studied (Figure 1) for both IFAT and ELISA. Of 405 sera studied, 36.05\% were positive and $63.95 \%$ negative for IFAT and 39.5\% were positive and $60.5 \%$ negative for ELISA, varying according to goat sex and age (Table 2).

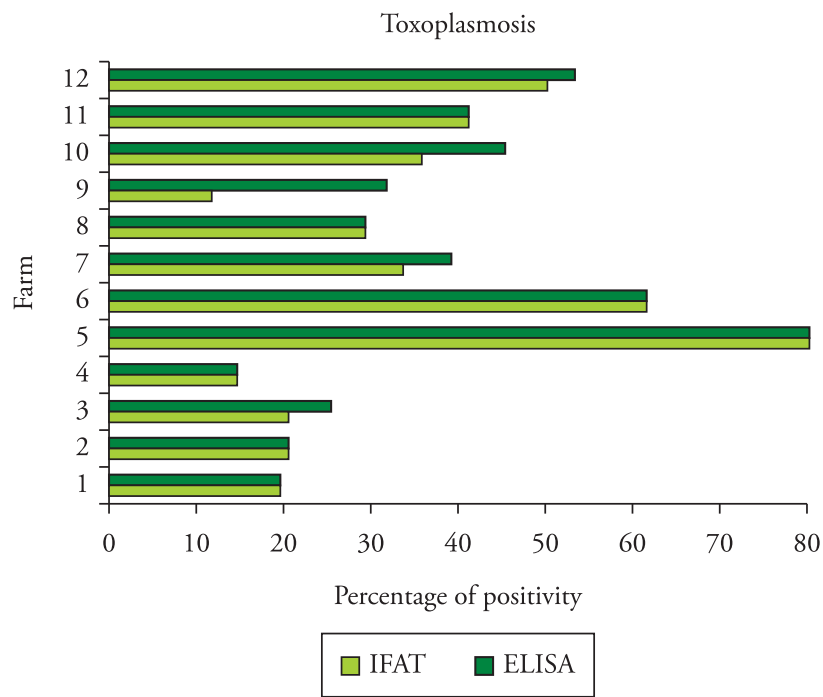

Figure 1. Prevalence of anti-Toxoplasma gondii antibodies in goats of different ages from 12 farms in the metropolitan mesoregion of Curitiba, State of Paraná, southern Brazil. 
Table 2. Serology results according to goat sex and age.

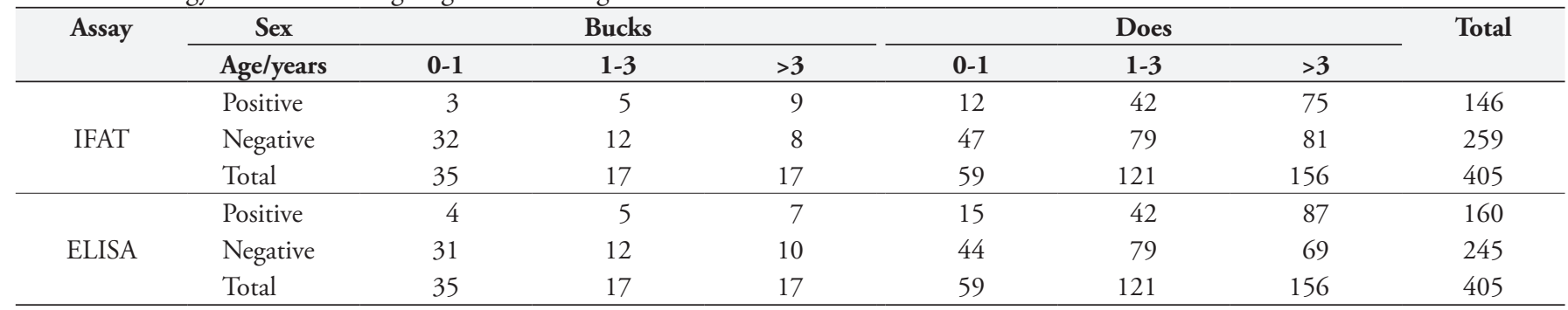

In regard to sex, $24.6 \%$ of bucks and $38.4 \%$ of does were seropositive by IFAT $\left(\chi^{2}=4.69 ; \mathrm{p}<0.05\right)$ while $23.1 \%$ of bucks and $42.9 \%$ of does were positive for toxoplasmosis by ELISA $\left(\chi^{2}=9.26 ; \mathrm{p}<0.05\right)$; the differences were statistically significant in both methods (Table 2).

As for age, by IFAT, $16 \%$ of goats younger than 1 year old, $34.1 \%$ of those 1 to 3 years old and $48.5 \%$ of those older than 3 years old were positive for toxoplasmosis $\left(\chi^{2}=28.4 ; \mathrm{p}<0.05\right)$ while by ELISA 20.2, 34.1, and 54.3 of goats, respectively, were positive $\left(\chi^{2}=32.3 ; \mathrm{p}<0.05\right)$ (Figure 2 ); again, the differences were statistically significant in both methods. The amount of serum reagents increased with goat age ( $\mathrm{z}$-test, $\mathrm{p}<0.05$ ).

Besides age, the main risk factors associated with anti-T. gondii antibodies are summarized in Table 3 . The relative risk (RR) for each factor was as follows: presence of cats near livestock $(R R=1.7$; $\mathrm{CI}: 1.34-2.17)$; access of cats to goat feeding $(\mathrm{RR}=1.81$; CI: $1.42-2.31)$; type of semi-intensive management $(R R=2.88$; $\mathrm{CI}: 1.38-6.03)$; and mixed breeding function $(\mathrm{RR}=1.42$; CI: $1.11-1.81)$.

\section{Discussion}

The prevalence of anti- $T$. gondii IgG antibodies in goats in the metropolitan mesoregion of Curitiba was $39.5 \%$ by ELISA and $36.05 \%$ by IFAT. However, the prevalences ranged from 14.3 to $80.0 \%$ in individual farms.

The mean prevalence found in the current study was greater than that reported in Londrina, State of Paraná (30.71\%) (SELLA et al., 1994), in Rio Grande do Sul (30\%) (MACIEL; ARAÚJO, 2004) and São Paulo (23.4\%) (MODOLO et al., 2008). However, the prevalence found was lower than that reported in Minas Gerais, 68 and 43\% reported by Chiari et al. (1987) and Carneiro et al., (2009), respectively. These differences could be due to different serological techniques and cutoffs used in the studies, different type of animal handling and geographical region, and climate changes over the last few years.

The analysis of the results showed that the prevalence of toxoplasmosis increase with goat age, and that age is a risk factor for infection. This is because older goats have been exposed to oocysts present in the environment for a longer period of time, which increases the likelihood of exposure to the parasite (SELLA et al., 1994; JITTAPALAPONG et al., 2005; CAVALCANTE et al., 2008). As for sex, the proportion of seropositive does was greater than that of bucks. This can be explained by the fact that the mean

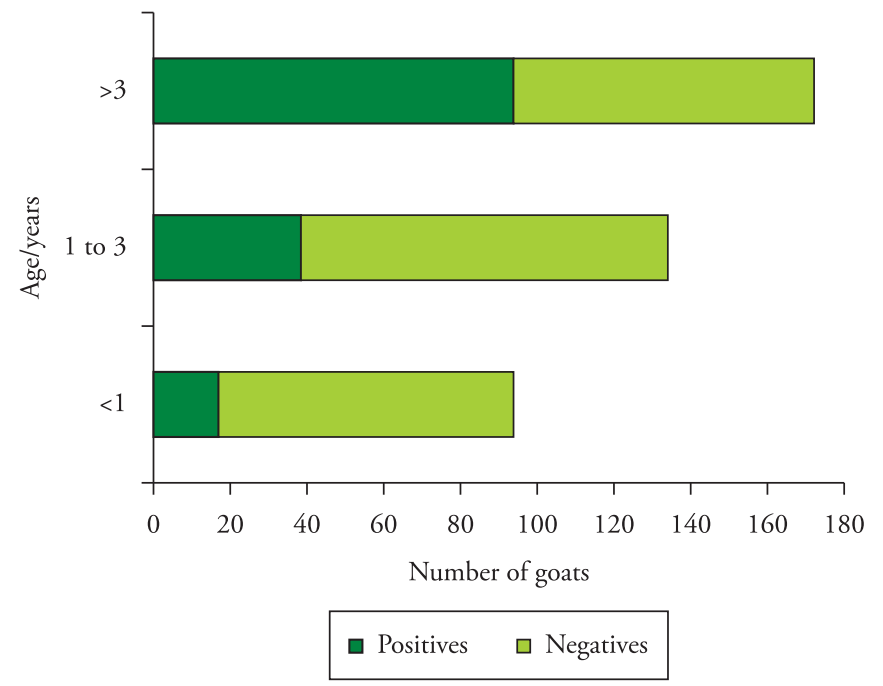

Figure 2. Seroprevalence of anti-Toxoplasma gondii antibodies determined by microplate-ELISA according to age.

age of bucks was lower than that of does because, while bucks are slaughtered before reaching one year of age, does are kept for reproduction and milk production.

A positive association was found between high toxoplasmosis prevalence and presence of cats living close to livestock. Felines play an important role in the transmission of infection due to the elimination of oocysts in their feces, thus contaminating the environment. The access of cats to the area where goat food is stored was also a major risk factor, as well as the type of feed cats were provided; in farms where cats were fed with cat food, the positive rates were lower than those in farms where cats hunted for food.

A higher prevalence of toxoplasmosis was seen in farms located in periurban compared to rural areas. This is due to the fact that population density and dynamics of definitive and intermediate hosts vary between urban and rural environments. Bisson et al. (2000) also reported similar differences, as did Kamani et al. (2010) and Thomaz-Soccol et al. (2009) for this or other animal species. Lower infection rates were seen in goats under intensive handling system. Figueiredo et al. (2001) and Araújo Neto et al. (2008) have both reported that extensive/semi-extensive handling systems are risk factors associated with anti-T. gondii antibodies. Goats raised under these farming systems are more likely to be exposed to oocysts shed by wild and domestic felines on pastures.

Greater serum prevalence was also seen among dairy compared to meat goats. Goats used for milk production have a higher mean 
Table 3. Risk factors associated with anti-Toxoplasma gondii antibodies, by ELISA.

\begin{tabular}{lccc}
\hline \multicolumn{1}{c}{ Risk factors } & Number of samples & Number of positives & Positive rate (\%) \\
\hline Exposure to cats & 143 & 77 & 53.8 \\
Access of cats to food & 257 & 110 & 42.8 \\
Semi-intensive handling & 378 & 156 & 41.2 \\
Mixed breeding function & 153 & 74 & 48.3 \\
\hline
\end{tabular}

age than those raised for slaughter, thereby increasing their likelihood of contamination. Exclusively dairy herd farms were not studied in the current study, but high seropositivity was determined in mixed-exploration herds (milk and meat).

The current study showed that does are a group at risk of infection. As abortions and fetal damage only occur during the acute phase of infection, does with chronic infection are no longer a reason for concern for the breeder since they can be considered immune to the disease. However, it is necessary to monitor food and water provided to serum negative goats, particularly during breeding and gestational periods, when problems may occur.

Since herbivorous are mainly infected through oocyst ingestion, the elimination of cats from goat farms is recommended, or cats should be provided cat food, because serum prevalence was lower in farms where cats were fed with cat food. However, this is not a solution to the problem as other cats living in the area or wild felines can also eliminate oocysts and most breeders keep cats to control rodents and pests. Thus, it is very difficult to convince them of the need to eliminate the presence of felines. It should also be emphasized that chronically infected cats can hardly excrete oocysts, and therefore they do not pose a risk in this case. The focus should be on younger cats. These recommendations should be given to breeders because knowledge of the risks can help implement control measures to reduce infection during gestational periods. Thus, the best way to control infection is to protect goat feed from exposure to cats and the herd should be provided with water from a reliable source.

The current study identified the risks of toxoplasmosis infection in goats, and one should bear in mind that this animal species is part of the human food chain and people can become infected by drinking milk or eating raw or undercooked meat. This species should not be overlooked as a source of infection, especially for pregnant women. Vaz et al. (2010) showed that the group at risk of infection is around $46.07 \%$ and the seroconversion rate was $0.16 \%$. To minimize the risks of prenatal infection and consequently fetal sequelae, pregnant women should be educated about the risks of drinking milk or eating raw or undercooked meat of this species and other animals.

The analyses of serological and epidemiological data in the current study allow to conclude that the mean prevalence of toxoplasmosis infection in goat livestock in the metropolitan mesoregion of Curitiba varied according to property studied, from 11.4 to $80 \%$, and that the prevalence of $T$. gondii antibodies in goats increased with age. Besides age, the other main risk factors for goat toxoplasmosis are presence of cats living close to livestock, access of cats to goat feed, semi-intensive handling and mixedexploration herds. Knowing serum prevalence of toxoplasmosis in goat livestock can help develop and implement infection control measures.

\section{Acknowledgements}

The authors are grate to the goat breeders for allowing to studying their animals. The authors would also like to thank CAPES for its financial support.

\section{References}

Alves CJ, Vasconcellos SA, Navarro IT, Barbosa CS. Avaliação de aglutininas anti-Toxoplasma em soros de caprinos de cinco centros de criação do nordeste do Brasil. Rev Bras de Ciências Vet 1997; 4(2): 75-77.

Araújo Neto JOA, Azevedo SS, Gennari SM, Funada MR, Pena HFJ, Araújo ARCP, et al. Prevalence and risk factors for anti-Toxoplasma gondii antibodies in goats of the Seridó Oriental Microregion, Rio Grande do Norte State, Northeast region of Brazil. Vet Parasitol 2008; 156: 329-332. PMid:18583058. http://dx.doi.org/10.1016/j.vetpar.2008.05.013

Bisson A, Maley S, Rubaire-Akiiki CM, Wastling JM. The seroprevalence of antibodies to Toxoplasma gondii in domestic goats in Uganda. Acta Trop 2000; 76(1): 33-38. http://dx.doi.org/10.1016/S0001706X(00)00086-3

Blewett DA. The epidemiology of ovine toxoplasmosis. I. The interpretation of data for the prevalence of antibody in sheep and other host species. BVJ 1983; 139(6): 537-545.

Borde G, Lowhar G, Adesiyum A. Toxoplasma gondii and Chlamydophila abortus in caprine abortions in Tobago: a sero-epidemiological study. J Vet Med-B 2006; 53(4): 188-194. PMid:16629987. http://dx.doi. org/10.1111/j.1439-0450.2006.00931.x

Bradford MM. A rapid and sensitive method for the quantitation of microgram quantities of protein utilizing the protein-dye binding. Anal Biochem 1976; 72(1): 248-254. http://dx.doi.org/10.1016/00032697(76)90527-3

Camargo ME. Improved technique of indirect immunofluorescence for serological diagnosis of toxoplasmosis. Rev Inst Med Trop São Paulo 1964; 6(3): 117-118.

Carneiro ACAV, Carneiro M, Gouveia AMG, Guimarães AS, Marques APR, Vilas-Boas LS, et al. Seroprevalence and risk factors of caprine toxoplasmosis in Minas Gerais, Brazil. Vet Parasitol 2009; 160(3): 225-229. PMid:19091475. http://dx.doi.org/10.1016/j. vetpar.2008.10.092

Cavalcante ACR, Carneiro M, Gouveia AMG, Pinheiro RR, Vitor RWA. Risk factors for infection by Toxoplasma gondii in herds of goats in Ceará, Brazil. Arq Bras Med Vet Zoo 2008; 60(1):36-41. http://dx.doi. org/10.1590/S0102-09352008000100006

Chiari CA, Lima WS, Lima JD, Antunes CMF. Soro-epidemiologia da toxoplasmose caprina em Minas Gerais, Brasil. Arq Bras Med Vet Zoo 1987; 39(4): 587-609. 
Dubey JP. Toxoplasmosis. Veterinary Clinics of North America. Small Anim Prac 1987; 17(6): 1389-1404.

Faria EB, Gennari SM, Pena HFJ, Athayde ACR, Silva MLCR, Azevedo SS. Prevalence of anti-Toxoplasma gondii and anti-Neospora caninum antibodies in goats slaughtered in the public slaughterhouse of Patos city, Paraíba state, Northeast region of Brazil. Vet Parasitol 2007; 149(1/2): 126-129. PMid:17706359. http://dx.doi.org/10.1016/j. vetpar.2007.07.009

Feldman H, Miller L. Serological study of toxoplasmosis prevalence. Am J Epiemiol 1956; 64(3): 320-335.

Figliuolo LP, Rodrigues AAR, Viana RB, Aguiar DM, Kasai N, Gennari SM. Prevalence of anti-Toxoplasma gondii and anti-Neospora caninum antibodies in goat from São Paulo state, Brazil. Small Ruminant Res 2004; 55(1-3): 29-32. http://dx.doi.org/10.1016/j. smallrumres.2003.12.013

Figueiredo JF, Silva DAO, Cabral DD, Mineo JR. Seroprevalence of Toxoplasma gondii Infection in Goats by the Indirect Haemagglutination, Immunofluorescence and Immunoenzymatic Tests in the Region of Uberlândia, Brazil. Mem Inst Oswaldo Cruz 2001; 96(5): 687-692. http://dx.doi.org/10.1590/S0074-02762001000500019

Frenkel JK, Dubey JP, Miller NL. Toxoplasma gondii in cats: fecal stages identified as coccidian oocysts. Science 1970; 167: 893-896. PMid:4903651. http://dx.doi.org/10.1126/science.167.3919.893

Freyre A, Bonino J, Falcón J, Castells D, Correa D, Casaretto A. The incidence and economic significance of ovine toxoplasmosis in Uruguay. Vet Parasitol 1999; 81(1): 85-88.

Haberman SJ. The analysis of residuals in cross-classified tables. Biometrics 1973; 29(1): 205-220. http://dx.doi.org/10.2307/2529686

Jittapalapong S, Sangvaranond A, Pinyopanuwat N, Chimnoi W, Khachearam W, Koizumi S, et al. Seroprevalence of Toxoplasma gondii infection in domestic goats in Satun Province, Thailand. Vet Parasitol 2005; 127(1): 17-22. PMid:15619370. http://dx.doi. org/10.1016/j.vetpar.2004.08.019

Kamani J, Mani AU, Egwu GO. Seroprevalence of Toxoplasma gondii infection in domestic sheep and goats in Borno State, Nigeria. Trop Anim Health Pro 2010; 42(4): 793-797. PMid:19882227. http://dx.doi. org/10.1007/s11250-009-9488-3

Maciel KP, Araújo FAP. Inquérito sorológico para detecção de anticorpos de Toxoplasma gondii em caprinos (Capra hircus) criados nos municípios de Gravataí e Viamão, região da Grande Porto Alegre, Rio Grande do Sul, Brasil. Rev Ciência Agrovet 2004; 3(2): 121-125.

Mainardi RS, Stachissini AVM, Langoni H, Padovani CR, Modolo JR. Soroprevalência de Toxoplasma gondii em rebanhos caprinos no estado de São Paulo. Rev Bras Parasitol Vet 2000; 9(2): 97-99.

Meireles LR, Galisteo Junior AJ, Andrade Junior F. Serological survey of antibodies to Toxoplasma gondii in food animals from São Paulo state, Brazil. Braz J Vet Res Anim Sci 2003; 40(4): 267-271. http://dx.doi. org/10.1590/S1413-95962003000400005

Modolo JR, Langoni H, Padovani CR, Barrozo LV, Leite BLS, Gennari SM, et al. Avaliação da ocorrência de anticorpos anti-Toxoplasma gondii, em soros de caprinos do estado de Sáo Paulo, e associaçáo com variáveis epidemiológicas, problemas reprodutivos e riscos à saúde pública.
Pesq Vet Bras 2008; 28(12): 606-610. http://dx.doi.org/10.1590/S0100736X2008001200008

Munday BL, Manson RW. Toxoplasmosis as a cause of perinatal death in goats. Aust Vet J 1979; 55(10): 485-487. PMid:539933. http://dx.doi. org/10.1111/j.1751-0813.1979.tb00375.x

Pita-Gondim LF, Barbosa JHV, Ribeiro Filho CHA, Saeki H. Serological survey of antibodies to Toxoplasma gondii in goats, sheep, cattle and water buffaloes in Bahia state, Brazil. Vet Parasitol 1999; 82(4): 273-276. http://dx.doi.org/10.1016/S0304-4017(99)00033-3

Sella MZ, Navarro IT, Vidotto O, Freire RI, Shida PN. Epidemiologia da toxoplasmose caprina: Levantamento sorológico do Toxoplasma gondii em caprinos leiteiros na Micro Regiāo de Londrina, Paraná, Brasil. Rev Bras Parasitol Vet 1994; 3(1): 13-16.

Silva AV, Cunha ELP, Meireles LR, Gottschalk S, Mota RA, Langoni $\mathrm{H}$. Toxoplasmose em ovinos e caprinos: estudo soroepidemiológico em duas regiōes do estado de Pernambuco, Brasil. Ciênc Rural 2003; 33(1): 115-119. http://dx.doi.org/10.1590/S0103-84782003000100018

Silva AV, Cutolo AA, Langoni H. Comparação da reação de imunofluorescência indireta e do método de aglutinaçáo direta na detecção de anticorpos anti-Toxoplasma em soros de ovinos, caprinos, caninos e felinos. Arq Inst Biol 2002; 69(1): 7-11.

Silva Filho MF, Erzinger E, Cunha IAL, Bugni FM, Hamada FN, Marana ERM, et al. Toxoplasma gondii: abortion outbreak in a goatherd from Southern Brazil. Semina 2008; 29(4): 887-894.

Skinner LJ, Timperley AC, Wightman D, Chatterton JMW, Ho-Yen DO. Simultaneous diagnosis of toxoplasmosis in goats and goatowner's family. Scand J Infect Dis 1990; 22(3) 359-361. PMid:2371548. http://dx.doi.org/10.3109/00365549009027060

Skjerve E, Waldeland H, Nesbakken T, Kapperud G. Risk factors for the presence of antibodies to Toxoplasma gondii in Norwegian slaughter lambs. Prev Vet Med 1998; 35(3): 219-227. http://dx.doi.org/10.1016/ S0167-5877(98)00057-9

Tenter AM, Heckeroth AR, Weiss LM. Toxoplasma gondii: from animals to humans. Internat J Parasit 2000; 30: 1217-1258. http://dx.doi. org/10.1016/S0020-7519(00)00124-7

Thomaz-Soccol V, Castro EA, Gazda TL, Garcia G, Richartz RRTB, Dittrich RL. Ocorrência de anticorpos anti-Toxoplasma gondii em ovinos das áreas urbanas e periurbanas de Curitiba, Paraná. Rev Bras Parasitol Vet 2009; 18(1): 69-70.

Thrusfield MV. Epidemiologia Veterinária. $2^{\text {nd }}$ ed. São Paulo: Roca, 2004.

Uzêda RS, Fernández SY, Jesus EEV, Pinheiro AM, Ayres MCC, Spinola $S$, et al. Fatores Relacionados à Presença de Anticorpos IgG anti-Toxoplasma gondii em Caprinos Leiteiros do Estado da Bahia. Rev Bras Saúde e Prod Animal 2004; 5(1): 1-8.

Vaz RS, Thomaz-Soccol V, Sumikawa E, Guimarães ATB. Serological prevalence of Toxoplasma gondii antibodies in pregnant women from Southern Brazil. Parasitol Res 2010; 106(3): 661-665. PMid:20084396. http://dx.doi.org/10.1007/s00436-009-1716-2

Vitor RWA, Pinto JB, Chiari CA. Eliminação de Toxoplasma gondii através de urina, saliva e leite de caprinos experimentalmente infectados. Arq Bras Med Vet Zoo 1991; 43(2): 147-154. 